\title{
ASSESSING THE UTILITY OF RETAILER BASED ON GENERALIZED COSTS OF END-CONSUMERS
}

\author{
Andrii HALKIN \\ O. M. Beketov National University of Urban Economy in Kharkiv, Kharkiv, UKRAINE \\ galkin.ts1@gmail.com
}

\begin{abstract}
This paper gives a methodology to estimate the generalized costs of end-consumers visiting any retailer. The attractiveness and utility of retailers for end-consumers have been calculated based on their possible generalized costs according to their choice. According to the developed model, analysis of the consumer market visiting all shops in the described zone has been made. Research provides explanation of generalized costs of end-consumers. Generally, the utility function of end-consumers visiting retailers depends on the price and non-price factors. The regression models describing the time spent on transit to a retailer and inside of it provide monetary assessment of costs associated with the purchase process. The monetary level of fatigue was evaluated using the calories spent during the purchase process. The attractiveness of the retailer in an urban zone was assessed as an inverse function of the generalized costs.
\end{abstract}

Kaywords: end-consumers, zone, non-linearity factor, slope factor, generalized costs.

JEL Classification: M30, M31, M39, L66.

1

\section{Introduction}

Saving the leisure time tendency, especially in developed countries, force buyers seek new ways to save their generalized costs while purchase mobility (Galkin, et al., 2019a). The consumer's generalized costs are based on the elements of the process of shopping activity (Halkin, et al., 2019). The duration of these elements and their arrangement may vary depending on the aims of purchases purpose and the way of its implementation: customary (in the store), e-purchases, and so on (Russo and Comi, 2012). As a result, the generalized cost is formed of two groups of costs affecting consumer spending: product buying costs and the cost associated with purchase (direct and hidden). The latter one is difficult to reveal, evaluate, and assess, mostly because of the personal behavior of the buyer. The degree of impact of cost associated with purchase become higher with increase of salary, increasing level of service, increasing level of comfort, and so on, and vice versa. The rising interest in the high-quality products at low prices, saving time or minimizing the level of fatigue during the purchase elements, stimulates development of utility of endconsumers. Assessment of the costs and benefits of clients uncovers new opportunities for improving their service, overestimates efficiency of the logistics system, and provides a new concept for consumerproduction collaboration, which aims to increase joint efficient functioning (Galkin, et al., 2019b).

The purpose of the paper is to assess the utility of retailer based on generalized costs of end-consumers.

\section{$2 \quad$ Methodology}

\subsection{Conceptual framework}

Businesses are paying a lot of attention to studying their customers, to increase their utility and comfort, minimize fatigue, and to attract choosing needed retailer. Generally, the utility function of end-consumers depends on the price (Nakaya, et al., 2000; Scott, 2017) and non-price factors (Birkin, et al., 2017; MacInnis, et al., 2014; Oruc and Tihi, 2012). At the same time, such methods do not fully reflect modern market conditions. Certain parameters of existing models and methods do not provide a systematic approach to determining retailer visiting probability according to the generalized costs of end-consumer factors (Galkin, Dolia and Davidich, 2018).

The generalized costs approach is an important factor influencing the ability of purchases. Therefore, in modern logistics system, the maximum effect will come from a technology that can assess and manage 
the costs of consumers. Different ratios and sizes of these costs could affect consumer's behavior utility (Galkin, et al., 2019a). The generalized costs consist of monetary expression of the purchase of goods, monetary costs estimate of the travel time spent on purchases, monetary expression of the energy value spent on purchases, monetary expression of expenses of other non-price factors, cost related to delivery, and the values based on the elements of purchase process: time spent on the way to the retailer and back; time spent searching, waiting, getting acquainted with the goods in the store and their selection, cash accounting, and so on. In a particular case, the time consuming costs associated with the level of service offered: expectations of service, the degree of compliance with the timetable or schedule, the presence of goods, the organization of shopping services, the level of organization of the work of personnel, and so on.

The generalized costs of visit by residents of the $\omega$-th neighborhood of the $\mathrm{z}$ zone that visits the j-retailer (Galkin, et al., 2018) are given as:

$$
\Theta_{\text {total }}^{\mathrm{wj}}=\Theta_{1}^{\omega \mathrm{\omega j}}+\Theta_{2}^{\omega \mathrm{jj}}+\Theta_{3}^{\omega \mathrm{\omega j}}+\Theta_{4}^{\omega \mathrm{jj}}+\Theta_{5}^{\omega \mathrm{\omega j}} \rightarrow \min
$$

where:

$\omega$ - number of consumer's zones, $\omega=1,2, \ldots, \mathrm{I}$;

$\mathrm{j}$ - number of stores in the trade urban zone, $\mathrm{j}=1,2$, ..., J;

$\mathrm{z}$ - number of trade urban zone, $\mathrm{z}=1,2, \ldots, \mathrm{Z}$;

$\Theta_{1}^{\omega j}$ - monetary expression of the shopping time spent on purchases (UAH);

$\Theta_{2}^{\omega \mathrm{j}}$ - monetary costs on the purchase of goods in the j-retailer (UAH);

$\Theta_{3}^{\omega j}-$ monetary expression of the energy (fatigue) spent on purchases (UAH);

$\Theta_{4}^{\omega j}$ - monetary expression of other non-price factors (UAH), and

$\Theta_{5}^{\omega \mathrm{j}}-$ cost related to delivery (UAH).

The research hypothesis is based on the choice of the retailer by a certain group of customers (the consumer group), based on the generalized costs that they would incur as a result of their choice. Each consumer choice leads to costs generation. The purchase method determines the option and parameters of the purchase process. In the traditional shopping through a retailer, the consumer chooses a way of moving: by public or individual, if it is available, transport. Depending on the transport mode, the end-consumer determines the routes, the parameters of which affect the origindestination transit time and the fatigue that is caused. After arriving at the retailer, the end-consumer spends time and calories there (shopping service). After that, the end-consumer needs to return to his destination (home, work, etc.) and deliver his/her goods. When choosing an online shopping method, these stages are missing. The final stage is after-sales, which includes assessment of the results of the purchase, consumption, and deprivation of the used goods.

The particular purchase process elements are described by two groups of parameters: inside and outside of retailer (Galkin, et al., 2019a). The first group includes the parameters that affect the buyer on the way to the shop; some of them are the distance to the shop (Bucklin, 1967), the speed and time spent to get to the store and way back (Paroli and Maraschin, 2018), age of the consumer (Bradski, 1998), and so on. The second group of factors directly affects the consumer in the shop. These include: the area (Kotler and Armstrong, 2010), the range of products (Nerlove, 1995), the number of sellers (Dąbrowska, 2011), lighting, the number of people in the queue (Erhun and Tayur, 2003), the quantity of cashboxes (Ibrahim and McGoldrick, 2017), commercial service (Noseworthy, et al., 2014), the amount of purchases (Hernandez and Biasiotto, 2001), and the quality of service (Strizhakova, et al., 2008). Following methods do not evaluate generalized costs of the consumers. Methods for assessing utility do not provide assessment of retailer on possible generalized costs according to all possible options.

\subsection{Estimation cost of the leisure time of end-consumer in the process of purchase process}

The time spent by a buyer on purchases is a cost-generating measurement. In general, human time can be divided into sleep (rest), work, and leisure time. Sleeping is a biological need, work is necessary for existence in society, and leisure time is the time of self-actualization, self-development of a person, and so on (Lemon and Verhoef, 2016). Shopping is a part of the leisure time, and the purchasing process 
is a specific product - the time resource that is produced by the transport system or shopping services. Classic purchase process (Kotler and Dubois, 2009) can be described as:

$$
\mathrm{t}_{\omega \mathrm{j}}^{\text {purch }}=\mathrm{t}_{\omega \mathrm{j}}^{\text {'walking }}+\mathrm{t}_{\mathrm{j} \omega}^{\prime \text { walking }}+\mathrm{t}_{\mathrm{j}}^{\mathrm{TS}}
$$

where:

$\mathrm{t}_{\omega \mathrm{j}}^{\prime \text { walking }}-$ travel time from zone $\omega$ to a retailer $\mathrm{j}(\mathrm{h})$,

$\mathrm{t}_{\mathrm{j} \omega}^{\prime \prime \text { walking }}$ - travel time from a retailer $\mathrm{j}$ to zone $\omega(\mathrm{h})$,

$\mathrm{t}_{\mathrm{j}}^{\mathrm{TS}}$ - time of visiting (staying at) $\mathrm{j}$ retailer $(\mathrm{h})$.

The purchasing process consists of consecutive elements: time of the retailer, time of the shopping service, and travel time from the retailer to the destination. The cost of an hour of leisure time by the buyer is determined by the formula (10):

$$
C_{t}^{\text {hour }}=\frac{\bar{S}_{\mathrm{pc}}}{\Phi_{\mathrm{ctf}}-\left(\Phi_{\mathrm{wff}}+\Phi_{\mathrm{fff}}\right)}
$$

where:

$\overline{\mathrm{S}}_{\mathrm{pc}}$ - the average salary of people in the area of research (UAH),

$\Phi_{\text {ctf }}$ - the timeframe of calendar time per month (year),

$\Phi_{\text {wff }}$ - the monthly fund of working time (h), and

$\Phi_{\text {fff }}$ - the monthly fund of free time (h).

Part of monthly leisure time is the time for purchase, cinema, theatres, and so on. Recently, in countries with a developed market economy, all forms of development of various forms of after-sales services to customers, such as the delivery of purchased goods to home, are increasingly being developed. Thus, in the traditional sense, for a buyer, the full price of a product includes the travel costs from the place of residence or work to the retailers and the cost of its time for the purchase of goods, the cost of time.

The monetary expression of costs estimate of the travel time spent on purchases is as follows:

$$
\Theta_{1}^{\omega \mathrm{j}}=\mathrm{C}_{\mathrm{\Pi \Pi \Gamma}} \cdot \mathrm{t}^{\text {purch }}
$$

where:

$\mathrm{t}^{\text {purch }}$ - purchase time (h), and

$\mathrm{C}_{\mathrm{II}}-$ cost of leisure time of the buyer $(\mathrm{UAH} / \mathrm{h})$.
Analysis of the technological process of purchases indicates dependence on the group of factors affecting the consumer during the road to the trading venue and during the shopping service. The travel time will depend on the following parameters:

$$
\begin{aligned}
& \mathrm{t}_{\mathrm{ij}}^{\prime \text { walking }}=\mathrm{f}\left(\delta_{\omega \mathrm{j}}^{\text {before }} ; R^{\omega j} ; \mathrm{L}_{\omega \mathrm{j}}\right) \\
& \mathrm{t}_{\mathrm{ji}}^{\prime \text { walking }}=\mathrm{f}\left(\delta_{\mathrm{j} \omega}^{\text {affer }} ; R^{\omega j} ; \mathrm{L}_{\mathrm{j} \omega}\right)
\end{aligned}
$$

where:

$\delta_{\omega i}^{\text {befire }}-$ the slope factor on the road from the zone $\omega$ and to the retailer $\mathrm{j}$,

$\delta_{j \omega}^{\text {afer }}-$ the slope factor on the road from the retailer $j$ to the zone $\omega$,

$\mathrm{R}^{\omega \mathrm{j}}$ - the nonlinearity factor, and

$\mathrm{L}_{\omega \mathrm{j}}$ - the distance between the zone $\omega$ to the retailer $\mathrm{j}$ $(\mathrm{km})$.

The shopping time at the retailer depends on its area:

$$
\mathrm{t}_{\mathrm{j}}^{\mathrm{TS}}=\mathrm{f}\left(\mathrm{S}_{\mathrm{j}}^{\text {shop }}\right)
$$

where:

$\mathrm{S}_{\mathrm{j}}^{\text {shop }}$ - size of the retailer $\mathrm{j}\left(\mathrm{m}^{2}\right)$.

The described regression models have shown simulation of the purchase process. These models can be used for macrosimulation in residential area.

\subsection{Estimation of the monetary costs of end- consumer fatigue}

Estimation of fatigue is carried out with the indicator energy cost of movement. This value characterizes the direction of the energy regulation channels in the human body (Drewnowski, 2011). For any consumer activity, energy is consumed (Kidwell, et al., 2008). The amount of energy expended depends on the amount of effort spent on one or another element of the consumption process. Estimation of the amount of energy expended is carried out in various ways, among which one can distinguish the cost of action (Keytel, et al., 2005), pulse based on built-in sensors (Baevskii, 2002), and so on.

Determining the cost estimate of the energy costs of the human body in the purchasing process is based on the analysis of the required amount of calories for human existence (Postanova, 2000). According 
to the normative documents, the daily consumption of calories for normal functioning is $2790.8 \mathrm{kcal}$ (Monsivais, et al., 2013). But this value may depend on gender, age, and the physical activity of a person. Difficulty valuation calorie value is $1 \mathrm{kcal}$ different due to different levels of income, the cost structure of the budget and human households, as well as different values of the products and their usefulness to humans (Halkin, et al., 2019).

The cost of human energy is proposed to be determined by dependence:

$$
\mathrm{S}_{\mathrm{KCal}}^{\mathrm{cr}}=\frac{\sum_{1}^{\mathrm{M}}\left(\mathrm{Q}_{\omega} \cdot \mathrm{P}_{\text {тина }}\right)}{\mathrm{ALF} \cdot \mathrm{T}_{\text {cons }}}
$$

where:

$\mathrm{Q}_{\omega}$ - an individual need for a material flow of one resident for a period of time living in the $\omega$-th zone for the analyzed period for normal functioning of the organism, kg/inhabitant (unit/inhabitant),

$\mathrm{P}_{\text {цина }}$ - material flow price, $\mathrm{UAH} / \mathrm{kg}$ (unit/inhabitant),

ALF - daily energy norm of the person (consumer) (kcal), and

$\mathrm{T}_{\text {cons }}$ - time of consumption of goods (days).

The process of consuming the goods is closely linked to the concept of the process of consumption. The cost of action in the process of consumption of goods is given by:

$$
E^{\text {cr }}=\sum_{p=1}^{p} E_{p}=E_{\omega}^{\text {prep }}+E_{\omega j}^{\prime m o v m}+E_{j}^{T S}+E_{j \omega}^{\prime \prime m o v m ~}+E_{\omega}^{\text {afsell }}
$$

where:

$E_{\omega}^{\text {prep }}$ - the value of energy consumption of the endconsumer at the preparatory stage of consumption, preceding the purchase, $\mathrm{kJ}$ (kcal),

$\mathrm{E}_{\omega \mathrm{j}}^{\prime \text { movm }}$ - the value of energy consumption of the endconsumer when traveling from the zone $\omega$ to the retailer j, kJ (kcal),

$E_{j}^{T S}$ - the value of energy consumption of the consumer during the shopping service in the $\mathrm{j}$-th retailer, $\mathrm{kJ}$ (kcal),

$\mathrm{E}_{\mathrm{j} \omega}^{\prime \prime m o v m}$ - the value of energy costs in the delivery of goods from the $\mathrm{j}$-th retailer to the zone $\omega$ destination, $\mathrm{kJ}$ (kcal), and
$\mathrm{E}_{\omega}^{\text {afsell }}$ - the value of energy consumption of the endconsumer after sales, $\mathrm{kJ}$ (kcal).

The choice of product depends on the amount of time spent on the purchase. Energy value of consumer actions in the process:

$$
\Delta \mathrm{E}=\mathrm{E}_{\mathrm{p}}-\mathrm{E}_{0}
$$

where:

$E_{p}$ - energy consumption in performance of the $p$-th element of the process of consumption, $\mathrm{kJ}$ (kcal),

$\mathrm{E}_{0}$ - the value of energy costs in the calm state, $\mathrm{kJ}$ (kcal), and

$E_{\omega j}^{\prime m o v m}$ - the value of energy consumption of the consumer when traveling from the origin $\omega$ to the retailer $\mathrm{j}, \mathrm{kJ}$ (kcal).

Estimation of the monetary value of energy costs can be done by the formula:

$$
\Theta_{3}^{\mathrm{ij}}=\mathrm{E}_{\omega \mathrm{j}}^{\mathrm{cI}} \cdot \mathrm{S}_{\mathrm{KCal}}^{\mathrm{cI}}
$$

where:

$\mathrm{E}_{\omega \mathrm{j}}^{\mathrm{cn}}$ - energy consumption of the consumer in the process of development of goods (kcal) and

$\mathrm{S}_{\mathrm{KCal}}^{\mathrm{cn}}-$ cost of 1 calorie (UAH/kcal).

The amount of energy consumption of the consumer during the road to the $\mathrm{j}$-th retailer and back to the $\omega$ th zone (delivery by the consumer himself/herself) is represented as follows:

$$
\begin{aligned}
& \mathrm{E}_{\omega \mathrm{j}}^{\prime \text { movm }}=\mathrm{f}\left(\delta_{\omega \mathrm{j}}^{\text {befire }} ; R_{\omega j} ; \mathrm{L}_{\omega \mathrm{j}}\right) \\
& \mathrm{E}_{\mathrm{j} \omega}^{\prime \prime m o v m}=\mathrm{f}\left(\delta_{\mathrm{j} \omega}^{\text {affer }} ; R_{\mathrm{j} \omega} ; \mathrm{L}_{\mathrm{j} \omega}\right)
\end{aligned}
$$

The value of energy costs of the human body during the shopping service in the $j$ retailer is given as:

$$
E_{j}^{\mathrm{TS}}=f\left(S_{j}^{\text {shop }}\right)
$$

Described theoretical notes are shown the possible to assess the utility of retailers for end-consumers, using generalized costs according to the parameters of the purchase process.

\subsection{Attractiveness of stores}

A probability is assigned to every retailer using the model: 


$$
P_{w j}=\frac{U_{w j}}{\sum_{j=1}^{J} U_{w j}}
$$

where:

$P_{w j}$ - probability of choosing the $j$-th retailer by the w-th end-consumer, and

$U_{w j}-$ utility of the $j$-th retailer for the w-th end-consumer.

The utility of choosing a retailer is possible based on an analysis of the generalized costs of end-consumer. The lower the costs incurred by the end-consumer as a result of his/her choice, the greater the utility of choosing a distribution channel and it is given as:

$$
\mathrm{U}_{\mathrm{ij}}=-\Theta_{\text {total }}^{\mathrm{wj}}
$$

From dependence (15), it can be seen that the attractiveness of choosing a retailer depends on the usefulness of one or another option for end-consumers. Simultaneously, from dependence (16) it can be seen that attractiveness has an inversely proportional effect on the possible costs when choosing an option.

The lower the costs incurred by end-consumers as a result of his/her choice, the more benefit (positive effect) the choice will bring him/her, and as a result, the greater will be the likelihood of retailer choice.
The probability of choosing a retailer we suggested is found as follows:

$$
P_{i j}=\frac{\left(-\Theta_{\text {total }}^{\mathrm{wj}}\right) \cdot N_{i}}{\sum_{j=1}^{J}\left(-\Theta_{\text {total }}^{\mathrm{wj}}\right) \cdot N_{\mathrm{w}}}
$$

where:

$\mathrm{N}_{\mathrm{w}}$ is the capacity of consumers in $w$-zone.

Dependence (17) shows that the attractiveness depends on the utility. At the same time, according to dependency (3), the utility has an inverse of the potential generalized cost choosing various options. The lower the costs incurred by an end-consumer after his or her choice, the greater utility this choice will bring to him/her and the higher will be the likelihood of visiting such a retailer.

\section{$3 \quad$ Results}

In order to find the initial values of the parameters of end-consumers and retailer, natural studies were conducted. The studies use a two-stage methodology for determining the relevant geographic retail market (Galkin, et al., 2019b): distance, the nonlinearity factor, slope factor, and so on (Figs. 1 and 2).

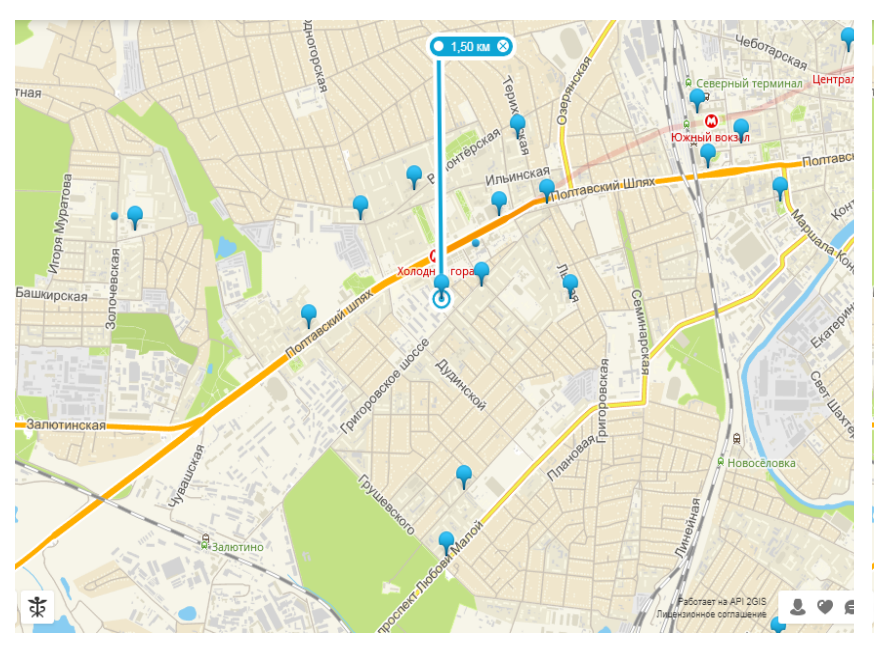

Figure 1. Trading area (Source: Authors' own research)

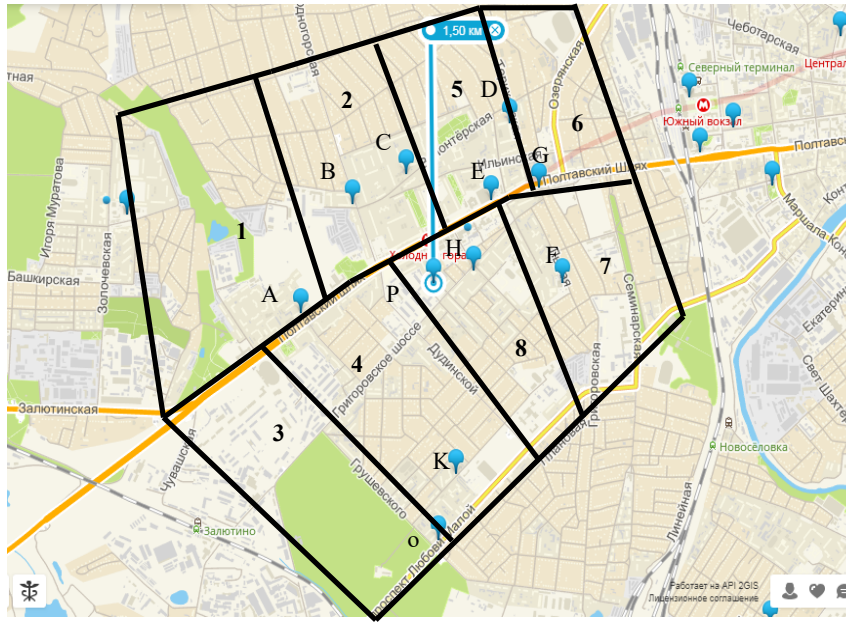

Figure 2. Adjusted trade area: $1, \ldots, 8$ - zones; A,..,G - stores (Source: Authors' own research) 
The research focused on visiting a retailer by end-consumers in the service area and monitoring the selected indicator: the number of calories consumed for a onetime visit to a retailer. For all consumers, a single set of goods (consumer basket) was selected. In general, 25 people (women and men) aged 19-65 participated in the study. The obtained data are presented in Tables 1 and 2.

Table 1. Output data for obtaining models of change in calories consumed (Source: Authors' own research)

\begin{tabular}{|c|c|c|c|c|c|c|c|c|c|c|}
\hline \multirow{2}{*}{ № } & \multicolumn{2}{|c|}{$\begin{array}{l}\text { Energy expenses } \\
\text { on the road, kcal. }\end{array}$} & \multicolumn{2}{|c|}{ Slope factor } & \multirow{2}{*}{$\begin{array}{l}\text { Non- } \\
\text { linearity } \\
\text { factor }\end{array}$} & \multicolumn{2}{|c|}{ Distance, $\mathrm{km}$} & \multirow{2}{*}{$\begin{array}{c}\text { Energy } \\
\text { expenses } \\
\text { at retailer, } \\
\text { kcal. }\end{array}$} & \multirow{2}{*}{$\begin{array}{c}\text { Size } \\
\text { of the re- } \\
\text { tailer, } \\
\mathrm{m}^{2}\end{array}$} & \multirow{2}{*}{$\begin{array}{c}\text { Total energy } \\
\text { expenses } \\
\text { per visit, } \\
\text { kcal. }\end{array}$} \\
\hline & $\begin{array}{l}\text { to } \\
\text { store }\end{array}$ & $\begin{array}{l}\text { from } \\
\text { store }\end{array}$ & $\begin{array}{l}\text { to } \\
\text { store }\end{array}$ & $\begin{array}{l}\text { from } \\
\text { store }\end{array}$ & & $\begin{array}{l}\text { by } \\
\text { air }\end{array}$ & $\begin{array}{l}\text { by } \\
\text { road }\end{array}$ & & & \\
\hline 1 & 45 & 49 & 0.990 & 1.010 & 1.23 & 0.57 & 0.7 & 8 & 700 & 102 \\
\hline 2 & 54 & 53 & 0.996 & 1.004 & 1.36 & 0.55 & 0.75 & 18 & 1408 & 125 \\
\hline 3 & 72 & 73 & 0.995 & 1.005 & 1.10 & 0.91 & 1 & 5 & 576 & 150 \\
\hline 4 & 37 & 39 & 0.987 & 1.013 & 1.31 & 0.42 & 0.55 & 9 & 500 & 85 \\
\hline .. & $\ldots$ & $\ldots$ & $\ldots$ & $\ldots$ & $\cdots$ & $\ldots$ & $\ldots$ & $\ldots$ & $\ldots$ & $\cdots$ \\
\hline 86 & 30 & 21 & 1.100 & 0.900 & 1.00 & 0.3 & 0.3 & 5 & 140 & 56 \\
\hline
\end{tabular}

Table 2. Output data for obtaining time changing models

(Source: Authors' own research)

\begin{tabular}{|c|c|c|c|c|c|c|c|c|c|c|}
\hline \multirow{2}{*}{ № } & \multicolumn{2}{|c|}{$\begin{array}{l}\text { Time movement, } \\
\text { min. }\end{array}$} & \multicolumn{2}{|c|}{ Slope factor } & \multirow{2}{*}{$\begin{array}{l}\text { Non- } \\
\text { linearity } \\
\text { factor }\end{array}$} & \multicolumn{2}{|c|}{ Distance, $\mathrm{km}$} & \multirow{2}{*}{$\begin{array}{c}\text { Time } \\
\text { of trade ser- } \\
\text { vice, } \\
\text { km }\end{array}$} & \multirow{2}{*}{$\begin{array}{c}\text { Size } \\
\text { of the store, } \\
\mathrm{m}^{2}\end{array}$} & \multirow{2}{*}{$\begin{array}{c}\text { Total } \\
\text { visiting time, } \\
\text { min. }\end{array}$} \\
\hline & $\begin{array}{c}\text { to } \\
\text { store }\end{array}$ & $\begin{array}{l}\text { from } \\
\text { store }\end{array}$ & $\begin{array}{l}\text { to } \\
\text { store }\end{array}$ & $\begin{array}{l}\text { by } \\
\text { air }\end{array}$ & & $\begin{array}{l}\text { by } \\
\text { air }\end{array}$ & $\begin{array}{l}\text { by } \\
\text { road }\end{array}$ & & & \\
\hline 1 & 10 & 11 & 0.990 & 1.010 & 1.23 & 0.57 & 0.7 & 19 & 700 & 40 \\
\hline 2 & 11 & 11 & 0.996 & 1.004 & 1.36 & 0.55 & 0.75 & 22 & 1408 & 44 \\
\hline$\ldots$ & $\ldots$ & $\ldots$ & $\ldots$ & $\ldots$ & $\ldots$ & $\ldots$ & $\ldots$ & $\ldots$ & $\ldots$ & $\ldots$ \\
\hline 86 & 6 & 4 & 1.100 & 0.900 & 1.00 & 0.3 & 0.3 & 12 & 140 & 22 \\
\hline
\end{tabular}

The experiment was performed using the Smart Watch U8 (Halkin, 2018) electronic clock, which calculated the number of meters passed, and the time and calories consumed for various elements of the purchasing process.

The set of products was determined according to the consumer basket of the Law of Ukraine (Kovyazina, 2014), as a set of food products, formed by the central executive body.

Processing of the research results was performed using regression and correlation analysis methods. The model for changing the energy consumption of the human body during the shopping service at the $\mathrm{j}$ retailer can be described with the following model:

$$
\mathrm{KCal}_{\mathrm{j}}^{\mathrm{TS}}=\sqrt{0,000232 \cdot \mathrm{S}_{\mathrm{j}}^{\text {shop }}}
$$

where $S_{j}^{\text {shop }}$ is the size of the $\mathrm{j}$ retailer $\left(\mathrm{m}^{2}\right)$.

The model for changing the time required to complete the purchasing process at retailer $\mathrm{j}$ can be described using the following model:

$$
\mathrm{t}_{\mathrm{j}}^{\mathrm{TS}}=\sqrt{0,386 \cdot \mathrm{S}_{\mathrm{j}}^{\text {shop }}}
$$

The results of calculations of statistical estimation are given in Table 3. 
Table 3. Results of model evaluation (Source: Authors' own research)

\begin{tabular}{|l|c|c|}
\hline \multicolumn{1}{|c|}{ Indicator } & Value for energy cost model & Value of the time cost model \\
\hline $\begin{array}{l}\text { Student Criterion: } \\
\text { - calculated }\end{array}$ & 1.97 & 1.97 \\
- actual & 122.712 & 32.0153 \\
\hline $\begin{array}{l}\text { Fischer Criterion: } \\
\text { - calculated }\end{array}$ & 3.88 & 3.88 \\
$\bullet \quad$ actual & 15058.24 & 1024.98 \\
\hline Correlation coefficient & 0.99 & 0.96 \\
\hline Determination coefficient & 0.89 & 0.92 \\
\hline
\end{tabular}

The model adequately reflects the fact that with the increase of retailer's size, energy costs are increased when making a purchase.

The model for changing the energy costs during walking distance from the origin to the retailer $\mathrm{j}$ and in the opposite direction is as follows:

$$
\mathrm{KCal}_{\omega \mathrm{\omega j}}^{\mathrm{movm}}=92,388 \cdot \mathrm{LOG}\left(\delta_{\omega \mathrm{j}}\right)+8,863 \cdot \mathrm{R}_{\omega \mathrm{j}}+78,092 \cdot 1_{\omega \mathrm{j}}
$$

The model for changing the walking time from the origin $i$ to the retailer $\mathrm{j}$ can be described with the following model:

$$
\mathrm{t}_{\mathrm{ij}}^{\text {walking }}=19,63 \cdot \operatorname{LOG}\left(\delta_{\omega \mathrm{j}}\right)+1,679 \cdot \mathrm{R}_{\omega \mathrm{j}}+15,438 \cdot 1_{\omega \mathrm{j}}
$$

The results of calculations of statistical estimation are given in Table 4.

Table 4. Results of model evaluation (Source: Authors' own research)

\begin{tabular}{|l|c|c|}
\hline \multicolumn{1}{|c|}{ Indicator } & $\begin{array}{c}\text { Value } \\
\text { for energy cost model }\end{array}$ & $\begin{array}{c}\text { Value } \\
\text { of the time cost model }\end{array}$ \\
\hline $\begin{array}{l}\text { Student Criterion: } \\
\text { - calculated }\end{array}$ & 1.97 & 1.97 \\
$\bullet \quad$ actual value of the slope factor & 2.007 & 2.281 \\
$\bullet \quad$ actual value of the none-linearity factor & 7.325 & 6.956 \\
$\bullet \quad$ actual value of the distance between the points "by air" & 67.64 & 66.097 \\
\hline Fischer Criterion: & & 3.88 \\
• calculated & & 6268.63 \\
\hline Correlation coefficient & 6730.09 & 0.99 \\
\hline Determination coefficient & 0.99 & 0.98 \\
\hline
\end{tabular}

The model adequately reflects the fact that with the increase in retailer size, energy (fatigue) costs are increased when making a purchase.
Assessing the utility of retailer presented via the O-D matrix of generalized cost of end-consumers (17). The generalized costs are calculated on models (2-21) and the results of calculations are given in Table 5. 
Table 5. OD matrix (Source: Authors' own research)

\begin{tabular}{|c|c|c|c|c|c|c|c|c|c|c|c|c|c|c|c|c|}
\hline \multirow{3}{*}{ Retailer } & \multicolumn{8}{|c|}{$\begin{array}{c}\text { Monetary expression } \\
\text { of shopping time spent on purchases, } \\
\text { UAH }\end{array}$} & \multicolumn{8}{|c|}{$\begin{array}{c}\text { Monetary expression } \\
\text { of the energy (fatigue) spent on purchases, } \\
\text { UAH }\end{array}$} \\
\hline & \multicolumn{8}{|c|}{ Zone } & \multicolumn{8}{|c|}{ Zone } \\
\hline & 1 & 2 & 3 & 4 & 5 & 6 & 7 & 8 & 1 & 2 & 3 & 4 & 5 & 6 & 7 & 8 \\
\hline A & 11.46 & 13.42 & 12.05 & 12.32 & 14.95 & 19.49 & 18.42 & 14.57 & 2.53 & 3.19 & 2.73 & 2.82 & 3.71 & 5.23 & 4.88 & 3.58 \\
\hline B & 10.26 & 9.68 & 15.75 & 13.62 & 11.70 & 15.20 & 16.47 & 13.73 & 1.79 & 1.62 & 3.40 & 2.78 & 2.22 & 3.24 & 3.61 & 2.81 \\
\hline $\mathrm{C}$ & 10.44 & 7.02 & 15.27 & 13.43 & 9.37 & 12.67 & 14.68 & 12.53 & 2.38 & 1.24 & 4.02 & 3.40 & 2.03 & 3.14 & 3.83 & 3.10 \\
\hline D & 14.90 & 9.33 & 18.02 & 14.62 & 6.67 & 7.66 & 11.22 & 11.74 & 3.57 & 1.92 & 4.52 & 3.50 & 1.12 & 1.41 & 2.49 & 2.64 \\
\hline E & 20.57 & 17.56 & 23.40 & 19.70 & 14.25 & 16.98 & 16.31 & 17.43 & 4.02 & 3.16 & 4.86 & 3.79 & 2.20 & 2.99 & 2.81 & 3.13 \\
\hline G & 16.08 & 14.43 & 18.54 & 13.91 & 8.28 & 9.55 & 8.87 & 9.91 & 4.12 & 3.57 & 4.96 & 3.40 & 1.50 & 1.93 & 1.70 & 2.06 \\
\hline $\mathrm{H}$ & 14.04 & 11.04 & 13.16 & 8.88 & 10.72 & 13.38 & 10.16 & 7.78 & 3.26 & 2.36 & 3.00 & 1.71 & 2.26 & 3.07 & 2.10 & 1.39 \\
\hline $\mathrm{F}$ & 16.84 & 13.61 & 15.67 & 10.48 & 11.70 & 12.35 & 6.77 & 5.52 & 4.60 & 3.52 & 4.22 & 2.47 & 2.88 & 3.10 & 1.22 & 0.80 \\
\hline K & 18.11 & 19.00 & 7.33 & 9.76 & 20.29 & 23.11 & 16.93 & 14.68 & 4.35 & 4.62 & 1.21 & 1.93 & 4.99 & 5.82 & 4.01 & 3.36 \\
\hline
\end{tabular}

Assessing the utility of retailer presented via the O-D matrix of generalized cost of end-consumers (1).
The generalized costs are calculated on models (2-21) and the results of calculations are given in Table 6 .

Table 6. Origin-Destination generalized costs matrix on visiting retailer from different origins (UAH) (Source: Authors' own research)

\begin{tabular}{|c|c|c|c|c|c|c|c|c|c|}
\hline \multirow{2}{*}{ Retailer } & \multicolumn{9}{|c|}{ Residential zones } \\
\cline { 2 - 10 } & 1 & 2 & 3 & 4 & 5 & 6 & 7 & 8 & 9 \\
\hline A & 57.4 & 61.6 & 60.6 & 55.7 & 58.7 & 54.4 & 57.7 & 55.1 & 60.2 \\
\hline B & 51.0 & 55.7 & 55.0 & 52.3 & 52.2 & 47.8 & 51.8 & 49.9 & 54.8 \\
\hline C & 67.7 & 65.6 & 63.0 & 63.8 & 68.9 & 63.5 & 63.5 & 59.6 & 55.9 \\
\hline D & 61.7 & 64.0 & 61.5 & 60.3 & 60.1 & 54.9 & 57.9 & 54.2 & 57.7 \\
\hline E & 57.6 & 59.4 & 57.0 & 55.0 & 56.9 & 51.7 & 55.2 & 49.4 & 56.8 \\
\hline F & 62.6 & 59.4 & 54.8 & 58.2 & 65.0 & 59.4 & 60.3 & 54.9 & 50.3 \\
\hline G & 57.7 & 60.1 & 55.8 & 55.7 & 57.0 & 51.7 & 54.7 & 49.1 & 51.0 \\
\hline H & 57.5 & 59.6 & 52.1 & 53.3 & 59.6 & 54.5 & 58.7 & 51.4 & 46.5 \\
\hline I & 61.5 & 60.5 & 55.7 & 57.3 & 62.2 & 58.0 & 60.3 & 53.3 & 50.0 \\
\hline K & 61.4 & 57.6 & 53.2 & 57.1 & 64.3 & 59.0 & 59.9 & 54.3 & 49.4 \\
\hline
\end{tabular}


The maximum value of the generalized cost was 67.7 UAH (2.5\$) and the minimum value was $46.5 \mathrm{UAH}$ (1.9\$). The set of products was determined according to the consumer basket of the Law of Ukraine, as a set of food products, formed by the central executive body.

The basic principles of forming a set of food products are: satisfaction of the body of the working person in reproduction of work, preservation of the work capacity for the unemployed, recovery in necessary cases of disability for the person who lost it, and maintenance of the full functioning of the human body of the elderly. Recent statistics show that in Ukraine, more than $50 \%$ use this set of goods.

With the attractiveness of visiting the retailer, it was possible to investigate the change in demand for the variation parameters of each of the systems, which are presented in Table 7 .

Table 7. Demand attractiveness matrix of visiting a retailers in described zone

(Source: Authors' own research)

\begin{tabular}{|c|c|c|c|c|c|c|c|c|c|c|}
\hline \multirow{2}{*}{ Retailer } & \multicolumn{9}{|c|}{ Residential zones } \\
\cline { 2 - 11 } & 1 & 2 & 3 & 4 & 5 & 6 & 7 & 8 & 9 & $\Sigma$ \\
\hline A & 0.0150 & 0.0104 & 0.0080 & 0.0206 & 0.0093 & 0.0055 & 0.0132 & 0.0113 & 0.0014 & $\mathbf{0 . 0 9 4 8}$ \\
\hline B & 0.0125 & 0.0095 & 0.0084 & 0.0177 & 0.0085 & 0.0055 & 0.0116 & 0.0103 & 0.0014 & $\mathbf{0 . 0 8 5 3}$ \\
\hline C & 0.0153 & 0.0091 & 0.0070 & 0.0227 & 0.0089 & 0.0050 & 0.0144 & 0.0121 & 0.0014 & $\mathbf{0 . 0 9 5 8}$ \\
\hline D & 0.0176 & 0.0122 & 0.0091 & 0.0260 & 0.0118 & 0.0064 & 0.0163 & 0.0140 & 0.0018 & $\mathbf{0 . 1 1 5 2}$ \\
\hline E & 0.0125 & 0.0095 & 0.0087 & 0.0183 & 0.0094 & 0.0064 & 0.0125 & 0.0111 & 0.0016 & $\mathbf{0 . 0 9 0 0}$ \\
\hline F & 0.0148 & 0.0115 & 0.0109 & 0.0217 & 0.0115 & 0.0080 & 0.0146 & 0.0129 & 0.0019 & $\mathbf{0 . 1 0 7 9}$ \\
\hline G & 0.0162 & 0.0109 & 0.0087 & 0.0263 & 0.0119 & 0.0064 & 0.0180 & 0.0155 & 0.0019 & $\mathbf{0 . 1 1 5 9}$ \\
\hline H & 0.0131 & 0.0080 & 0.0064 & 0.0218 & 0.0082 & 0.0047 & 0.0168 & 0.0141 & 0.0014 & $\mathbf{0 . 0 9 4 4}$ \\
\hline I & 0.0131 & 0.0085 & 0.0070 & 0.0219 & 0.0091 & 0.0052 & 0.0183 & 0.0189 & 0.0017 & $\mathbf{0 . 1 0 3 8}$ \\
\hline K & 0.0132 & 0.0097 & 0.0084 & 0.0202 & 0.0104 & 0.0064 & 0.0142 & 0.0127 & 0.0018 & $\mathbf{0 . 0 9 7 0}$ \\
\hline$\Sigma$ & $\mathbf{0 . 1 4 3 2}$ & $\mathbf{0 . 0 9 9 3}$ & $\mathbf{0 . 0 8 2 7}$ & $\mathbf{0 . 2 1 7 2}$ & $\mathbf{0 . 0 9 8 8}$ & $\mathbf{0 . 0 5 9 5}$ & $\mathbf{0 . 1 5 0 1}$ & $\mathbf{0 . 1 3 2 9}$ & $\mathbf{0 . 0 1 6 4}$ & $\mathbf{1}$ \\
\hline
\end{tabular}

The results of the calculations have shown the influence of the generalized costs on attractiveness of visiting retailer:

- A higher size of the retailer, slope factor, nonlinearity factor, distance to the retailer, and higher income of the end-consumers cause a higher value of cost associated with purchase.

- Lower level of fatigue (calorie spent) of the endconsumers ensures small size of the retailer, slope factor, nonlinearity factor, distance to the retailer, and low income of the end-consumers. Therefore, if the end-consumers what to lose they should choose vice versa retailers with higher value of named parameters.

- The presence of a large number of end-consumers increases attractiveness of any retailer in this zone.

- Retailers D and G will have the highest value of probability of visiting and retailer B the lowest due to high generalized costs in them.

- Number and assortment of goods and prices, and ultimately, the choice of retailer. 
This research provides further explanation of the attractiveness methods of visiting a retailer. The regression models that describe the time and energy of the end-consumers in and out of retailers were obtained. In contrast to the existing approach to planning and evaluating the generalized costs based on subjective opinions, our method is based on the real purchase process calculation in a particular zone.

The presented factors' variation range covers typical residential zone for Ukrainian town. The proposed approach can be applied to any other town, extending the variation range.

\section{Conclusions}

Improving the quality of customer service is one of the main areas for improving the trading today.

In a market economy, competition among traders is increasing, so businesses are paying a lot of attention to studying their customers, minimizing their costs, and creating the most favorable conditions for them for making purchases. As a result of the analysis, it was found that consumers have direct and indirect costs. The role of the latter one is not clearly defined in determining demand and choosing a logistics system.

The probability of choosing a retailer depends on a number of alternative options and the possible generalized costs spending on these options. Increasing the consumer's generalized costs will reduce the frequency of choosing this option and vice versa.

The generalized cost calculation of the consumer in the purchase process involves the monetary expression of expenses of the price (price of goods, cost related to delivery, etc.), the monetary expression of expenses of non-price factors, and the monetary expression of external expenses related to the transport network functioning, which allows more accurately to identify the attraction of the option for the end-consumer.

In practice, formulae (2) and (9) can be extended or changed according to the way of purchase, aims, and other factors. But generally, the mechanism of calculations can be used for all possible options with some changes in particular cases.
Research analysis indicates various methods for evaluating the cost of consumer's costs and the composition of such costs. This, in turn, complicates the calculations and makes ambiguity in the interpretation of the composition of consumption expenditure. Another problem is the integration of end-consumer into the distribution channel, and as a consequence, the possibility of determining the impact of them on the results. The indicators for assessing the operation of the distribution channel and society as a single system also need to be improved.

Change of fatigue (energy) and consumer's travel time expenditures during the trip from household to a retailer and in the opposite direction is adequately described via nonlinear regression equations developed in the paper. It is described using three variables: the slope factor, the nonlinearity factor, and the distance. Estimation showed that change of fatigue (energy) and consumer's travel time expenditures during the shopping inside of the retailer is adequately described via nonlinear regression equations with size factor.

The approach to estimation of the (fatigue) energy costs of end-consumers in visiting the retailers has been presented for the first time. For the first time, the energy costs (fatigue) in monetary form were determined depending on the purchase process parameters.

The developed model can be used for macro- and microsimulation of residential zones and assessing the probability of visiting retailers.

\section{$5 \quad$ References}

[1] Baevskii, R.M., 2002. Analysis of Heart Rate Variability in Space Medicine. Human Physiology, 28(2), pp.202-213.

[2] Birkin, M., Clarke, G. and Clarke, M., 2017. Retail Location Planning in an Era of Multi-Channel Growth. Routledge.

[3] Dąbrowska, A., 2011. Consumer Behaviour in the Market of Catering Services in Selected Countries of Central-Eastern Europe. British Food Journal, 113(1), pp.96-108. 
[4] Erhun, F. and Tayur, S., 2003. Enterprise-wide Optimization of Total Landed Cost at a Grocery Retailer. Operations Research, 51(3), pp.343353.

[5] Galkin, A., Balandina, I., Polchaninova, I. and Galkina, O., 2019b. Retail Trade Area Analysis Using Multiple Variables Modeling at Residential Zone. Vilnius Gediminas Technical University. https://doi.org/10.3846/cibmee.2019. 041.

[6] Galkin, A., Dolia, C. and Davidich, N., 2018. The Role of Consumers in Logistics Systems. Transportation Research Procedia, 27, pp.1187-1194.

[7] Galkin, A., Popova, Y., Bodnaruk, O., Zaika, Y., Chuprina, E., Shapovalenko, D. and Kolonataievskyi, O., 2019a. Attractiveness modeling of retail on emotional fatigue of consumers. The South East European Journal of Economics and Business, 14(2), pp.106-116.

[8] Halkin, A., 2018. Emotional State of Consumer in the Urban Purchase: Processing Data. Foundations of Management, 10(1), pp.99-112.

[9] Halkin, A., Bliumska-Danko, K., Smihunova, O., Dudnyk, E. and Balandina, I., 2019. Investigation Influence of Store Type on Emotional State of Consumer in the Urban Purchase. Foundations of Management, 11(1), pp.7-22.

[10] Hernandez, T. and Biasiotto, M., 2001. Retail Location Decision-Making and Store Portfolio Management. Canadian Journal of Regional Science, 24(3), pp.399-421.

[11] Ibrahim, M.F. and McGoldrick, P.J., 2017. Shopping Choices with Public Transport Options: an Agenda for the 21st Century. Routledge.

[12] Keytel, L.R., Goedecke, J.H., Noakes, T.D., Hiiloskorpi, H., Laukkanen, R., van der Merwe, L. and Lambert, E.V., 2005. Prediction of Energy Expenditure from Heart Rate Monitoring During Submaximal Exercise. Journal of Sports Sciences, 23(3), pp.289-297.

[13] Kidwell, B., Hardesty, D.M. and Childers, T.L., 2008. Consumer Emotional Intelligence: Conceptualization, Measurement, and the Prediction of Consumer Decision Making. Journal of Consumer Research, 35(1), pp.154-166.

[14] Kotler Ph., Dubois B., 2009. Marketing Management, 13e Editions, Paris,
[15] Kovyazina K.O., 2014. Schodo udoskonalennya metodiki viznachennya prozhitkovogo minimumu v ukrayini: analitichna zapiska (Concerning the Improvement of the Methodology for Determining the Subsistence Minimum in Ukraine: an Analytical Note). NatsIonalniy Institut strategIchnih dosIIdzhen pri PrezidentovI UkraYini.

[16] Lemon, K.N., and Verhoef, P.C., 2016. Understanding Customer Experience Throughout the Customer Journey. Journal of Marketing, 80(6), pp.69-96.

[17] MacInnis, D.J., Pieters, R. and Hoyer, W.D, 2014. 486670 Consumer Behaviour. Cengage Learning: Australia Pty Limited.

[18] Monsivais, P., Perrigue, M.M., Adams, S. L. and Drewnowski, A., 2013. Measuring Diet Cost at the Individual Level: a Comparison of Three Methods. European Journal of Clinical Nutrition, 67(11), pp.1220-1225.

[19] Nakaya, T., Fotheringham, A.S., Hanaoka, K., Clarke, G., Ballas, D. and Yano, K., 2007. Combining Microsimulation and Spatial Interaction Models for Retail Location Analysis. Journal of Geographical Systems, 9(4), pp.345-369.

[20] Nerlove, M., 1995. Hedonic Price Functions and the Measurement of Preferences: The case of Swedish Wine Consumers. European Economic Review, 39(9), pp.1697-1716.

[21] Noseworthy, T.J., Di Muro, F. and Murray, K.B., 2014. The Role of Arousal in Congruity-Based Product Evaluation. Journal of Consumer Research, 41(4), pp.1108-1126.

[22] Oruc, N. and Tihi, B., 2012. Competitive Location Assessment - the MCI Approach, South East European Journal of Economics and Business, 7(2), pp.35-49. DOI: https://doi.org/ 10.2478/v10033-012-0013-7

[23] Paroli, E. and Maraschin, C., 2018. Locational Attractiveness Modelling of Retail in Santa Maria, Brazil. Urban Science, 2(4), p.105.

[24] Postanova, K.M.U., 2000. Pro zatverdzhennya naborIv produktIv harchuvannya, naborIv neprodovolchih tovarIv ta naborIv poslug dlya osnovnih sotsIalnih $i$ demografIchnih grup naselennya (Pro Approved set of Products in the Archived, set of Unsatisfactory Goods that set in the Service of Basic social and demographic 
groups of the population). OfItskyniy Visnik UkraYini, 16, p.97.

[25] Russo, F. and Comi, A., 2012. The Simulation of Shopping Trips at Urban Scale: Attraction Macro-Model. Procedia - Social and Behavioral Sciences, 39, pp.387-399.
[26] Scott, P., 2017. Geography and Retailing. Routledge.

[27] Strizhakova, Y., Coulter, R.A. and Price, L.L., 2008. Branded Products as a Passport to Global Citizenship: Perspectives from Developed and Developing Countries. Journal of International Marketing, 16(4), pp.57-85. 